\title{
Gambaran Faktor Risiko Timbulnya Tuberkulosis Paru pada Pasien yang Berkunjung ke Unit DOTS RSUP Dr. M. Djamil Padang Tahun 2015
}

\author{
Nurul Husna Muchtar ${ }^{1}$, Deddy Herman ${ }^{2}$, Yulistini $^{3}$
}

\begin{abstract}
Abstrak
Tuberkulosis (TB) paru merupakan penyakit infeksi paru menular yang masih menjadi masalah kesehatan di dunia terutama di negara berkembang. Timbulnya penyakit Tuberkulosis paru sangat dipengaruhi oleh berbagai faktor. Tujuan penelitian ini adalah mengetahui gambaran distribusi frekuensi faktor risiko penyakit TB paru pada pasien yang berkunjung ke unit DOTS RSUP Dr. M. Djamil Padang tahun 2015. Penelitian ini merupakan penelitian deskriptif dengan menggunakan pendekatan cross sectional. Jumlah populasi adalah 77 orang, pengambilan sampel menggunakan metode consecutive sampling untuk mendapatkan 65 orang. Penelitian dilakukan dari bulan Januari hingga Oktober 2015 di Unit DOTS RSUP Dr. M. Djamil Padang. Data dianalisa secara komputerisasi dengan tampilan deskriptif dan disajikan dalam bentuk tabel. Didapatkan penderita TB paru dengan HIV negatif sebanyak 86,2 $\%$, tidak memiliki riwayat DM $87,7 \%$, memiliki status gizi kurang sebanyak $66,2 \%$ dan berdasarkan riwayat konsumsi alkohol 98,5\% bukan kelompok berisiko, serta $60 \%$ merupakan former smoker (mantan perokok). Sebagian besar penderita TB Paru tidak memiliki riwayat HIV, tidak memiliki faktor risiko DM dan berdasarkan riwayat konsumsi alkohol hampir semua pasien TB paru bukan kelompok risiko. Namun sebagian besar merupakan mantan perokok dan memiliki status gizi kurang.
\end{abstract}

Kata kunci: tuberkulosis paru, HIV, diabetes melitus, malnutrisi, alkohol, rokok

\section{Abstract}

Pulmonary tuberculosis is a contagious pulmonary infection and still a world-wide health challenge especially in developing countries. Pulmonary tuberculosis is affected by various factors. The objective of this study was to describe the frequency distribution of risk factors of pulmonary tuberculosis disease arising among patients attending DOTS unit of Dr. M. Djamil Padang Hospital in 2015. This cross sectional study was a descriptive research. Using consecutive sampling method, 65 sample of tuberculosis patients were obtained from a total population of 77 tuberculosis patients. The study was conducted from January to October 2015 in DOTS Unit of Dr. M. Djamil Padang Hospital. Data were computerized and presented as descriptive analyzed and tabular form. The pulmonary tuberculosis patients with HIVnegative are obtained as much as $86.2 \%$, without diabetic $87.7 \%$, malnutrition $66,2 \%$ and based on history of alcohol consumption $98,5 \%$ are the non-risk group, while $60 \%$ of them are former smoker. In this study, most of the pulmonary tuberculosis patients does not have history of HIV, without diabetic risk factors, and based on history of alcohol consumption almost all of the patients are the non-risk group. The most of them has malnutrition status and former smoker.

Keywords: pulmonary tuberculosis, HIV, diabetic, malnutrition, alcohol, smoking

Affiliasi penulis: 1. Prodi Pendidikan Dokter Fakultas Kedokteran Universitas Andalas Padang (FK Unand), 2. Bagian Penyakit Paru FK Unand/RSUP Dr. M. Djamil Padang, 3. Bagian Pendidikan Kedokteran FK Unand
Korespondensi: Nurul Husna Muchtar,

Email: childof_mn@yahoo.com, Telp: 085274840909 


\section{PENDAHULUAN}

Tuberkulosis (TB) paru merupakan penyakit infeksi paru menular yang masih menjadi masalah kesehatan di dunia terutama negara berkembang. Penyakit tuberkulosis sudah dicanangkan oleh WHO (World Health Organization) sebagai Global Emergency sejak tahun 1992. ${ }^{1}$

WHO memperkirakan antara tahun 2002 hingga 2020, 1000 juta orang akan terinfeksi, lebih dari 150 juta orang akan sakit dan 36 juta orang akan meninggal akibat TB jika kontrol kedepan tidak baik. ${ }^{2}$ Tuberkulosis merupakan pembunuh nomor satu diantara penyakit menular dan penyebab ke-3 kematian setelah penyakit jantung dan penyakit pernapasan akut di Indonesia. ${ }^{3}$ Di kota Padang, TB Paru termasuk kepada sepuluh penyebab terbanyak kematian. $^{4}$

Menurut Kementerian Kesehatan Republik Indonesia, tahun 2010 Indonesia telah mampu mencapai targetan MDGs (Millenium Development Goals) tahun 2015 yaitu dengan penurunan angka kematian menjadi 27 per 100.000 penduduk, proporsi kasus TB sebesar $78,3 \%$ dan proporsi keberhasilan pengobatan $91,2 \%$. Namun tetap perlu dilakukan persiapan program TB di dunia untuk mewujudkan dunia bebas TB yang diindikasikan dengan tidak ada lagi kematian karena TB. Kegiatan yang inovatif, program yang agresif dan penelitian yang baik diharapkan mampu membantu menurunkan prevalensi hingga 50 persen dari pencapaian pada tahun $2015 .{ }^{5}$

Risiko perkembangan infeksi TB menjadi sakit TB meningkat akibat penurunan sistem imun oleh Human Immunodeficiency Virus (HIV), diabetes melitus (DM), konsumsi alkohol, malnutrisi, merokok. ${ }^{6}$ Berdasarkan Global Report WHO tahun 2013 dalam Kementrian Kesehatan RI (2015) jumlah pasien TB dengan HIV positif di Indonesia meningkat dari 3,3\% pada tahun 2012 menjadi 7,5\% pada tahun $2013 .{ }^{7}$ Diabetes dan TB Paru di Poliklinik Penyakit Dalam RSUP Dr. M. Djamil Padang didapatkan sebanyak $4,5 \%{ }^{8}$ Di RSCM tahun 2010 pasien yang memiliki riwayat mengonsumsi alkohol $37 \%$ menderita TB paru. ${ }^{9}$ Prevalensi pasien TB dengan IMT (Indeks Masa Tubuh) rendah mencapai sekitar $80 \%$ pada penelitian yang dilakukan di RS Dr. Soedarso Pontianak ${ }^{10}$ dan di
RS Marguno Soekarjo Purwokerto didapatkan proporsi pasien TB paru dengan riwayat merokok $50 \%{ }^{11}$

Berdasarkan beberapa penelitian sebelumnya, perlu diteliti gambaran faktor risiko timbulnya tuberkulosis paru pada pasien yang berkunjung ke unit DOTS RSUP Dr. M Djamil Padang pada tahun 2015. Hasil penelitian ini diharapkan mampu mendukung diwujudkannya visi dunia bebas TB setelah pencapaian MDGs 2015.

\section{METODE}

Penelitian ini merupakan studi deskriptif dengan desain cross sectional yang telah dilakukan di Instalasi Rekam Medik RSUP Dr. M. Djamil Padang dan Unit DOTS RSUP Dr. M. Djamil Padang dari Januari sampai Oktober 2015.

Populasi penelitian adalah pasien TB Paru yang berkunjung ke Unit DOTS RSUP Dr. M. Djamil Padang pada tahun 2015. Pengambilan sampel menggunakan teknik consecutive sampling, sehingga didapatkan sampel yang memenuhi kriteria inklusi (pasien TB paru dewasa kasus baru dan masih dalam masa pengobatan OAT) dan memenuhi kriteria ekslusi (pasien yang tidak bersedia menjadi responden) sebesar 65 responden.

Data yang digunakan adalah data primer melalui kuisioner (untuk riwayat konsumsi alkohol dan merokok) dan data sekunder dari rekam medik (untuk riwayat HIV, DM, tinggi badan dan berat badan). Proses pengolahan data secara komputerisasi untuk analisis univariat agar diperoleh gambaran distribusi frekuensi faktor risiko timbulnya tuberkulosis paru.

\section{HASIL dan PEMBAHASAN}

Tabel 1. Distribusi frekuensi responden berdasarkan jenis kelamin

\begin{tabular}{ccc}
\hline Jenis Kelamin & $\mathbf{f}$ & $\%$ \\
\hline Laki- laki & 47 & 72,3 \\
Perempuan & 18 & 27,7 \\
\hline Umur (tahun) & $\mathbf{f}$ & $\%$ \\
\hline $18-25$ & 11 & 16,9 \\
$26-45$ & 25 & 38,5 \\
$>45$ & 29 & 44,6 \\
\hline Jumlah & 65 & 100 \\
\hline
\end{tabular}


Berdasarkan Tabel 1, tampak bahwa lebih dari separuh penderita TB paru merupakan laki- laki yaitu sebesar $72,3 \%$ dan umur terlihat bahwa penderita TB paru paling banyak pada umur diatas 45 tahun sebesar $44,6 \%$

Pada penelitian ini didapatkan 65 pasien TB paru sebagai responden $72,3 \%$ laki- laki. Hal ini sesuai dengan hasil penelitian Masniari di RS. Persahabatan yang mendapatkan jumlah penderita TB paru laki-laki sebanyak $61,7 \%{ }^{12}$ Alasan tingginya prevalensi TB pada laki-laki sebenarnya belum ada teori yang jelas, tetapi mungkin disebabkan karena aktivitas laki-laki yang lebih banyak di luar sehingga lebih berisiko untuk terpapar kuman TB dan beberapa teori juga menyatakan adanya perbedaan prevalensi infeksi, tingkat perkembangan dari infeksi penyakit, tidak terdeteksinya pelaporan untuk perempuan, atau adanya perbedaan dalam akses terhadap layanan kesehatan. ${ }^{13}$ Hal ini juga diperkuat dengan adanya kebiasaan merokok yang lebih banyak pada lakilaki. $^{14}$

Berdasarkan pengelompokan umur, didapatkan jumlah penderita TB paru tertinggi pada kelompok lansia >45 tahun (29 orang). Hasil ini sesuai dengan survei TB nasional yang menemukan jumlah penderita TB terbanyak pada kelompok umur diatas 45 tahun. ${ }^{15}$ Kejadian TB paru paling banyak pada lansia mungkin disebakan karena pada usia ini sudah mulai terjadi penurunan daya tahan tubuh, dan kondisi ini lebih rentan untuk terkena penyakit, terutama penyakit infeksi, salah satunya tuberkulosis.

Tabel 2. Distribusi frekuensi responden berdasarkan riwayat HIV

\begin{tabular}{ccc}
\hline HIV & f & $\%$ \\
\hline Positif & 9 & 13,8 \\
Negatif & 56 & 86,2 \\
\hline Jumlah & 65 & 100 \\
\hline
\end{tabular}

Berdasarkan Tabel 2, terlihat bahwa sebagian besar pasien TB paru tidak memiliki riwayat HIV yaitu sebesar $86,2 \%$

Hasil penelitian ini memperlihatkan bahwa terdapat 9 orang responden memiliki status HIV positif dengan persentase $13,8 \%$, sejalan dengan laporan WHO 2011 yang dikutip oleh Gooze dan Daley menyatakan secara global terdapat $14,8 \%$ pasien TB yang memiliki riwayat HIV dan di suatu wilayah di Afrika didapatkan $50-80 \%{ }^{16}$ Angka ini lebih tinggi dibandingkan angka estimasi nasional yang dilaporkan oleh Kementerian Kesehatan Republik Indonesia (Kemenkes RI) tahun 2011, dimana secara nasional estimasi prevalensi HIV pada pasien TB baru adalah $2,8 \%$. $^{17}$

Berdasarkan survei yang dilakukan di Unit DOTS RSUP Dr. M Djamil Padang hanya 33 orang dari 77 orang yang tercatatat di TB 03 sudah dikirim untuk melakukan screening HIV. Keputusan Menteri Kesehatan (KEPMENKES) RI Nomor 1278/MENKES/ SK/XII/2009 tentang Pedoman Pelaksanaan Kolaborasi Pengendalian Penyakit TB dan HIV bahwa pada daerah dengan epidemi HIV rendah dan terkonsentrasi, pasien yang memiliki faktor risiko HIV dirujuk ke Unit Pelayanan Konseling dan Tes HIV Sukarela (UPK KTS), sementara daerah dengan epidemi HIV yang meluas (prevalensi HIV pada pasien TB > 5\%) KTS harus ditawarkan secara rutin tanpa penilaian risiko. ${ }^{18}$

HIV merupakan penyakit infeksi virus yang menyebabkan gangguan sistem imun. Setelah menginfeksi tubuh seseorang, virus HIV menyerang dan merusak sel limfosit T-helper (CD4+), ${ }^{19}$ dimana sel limfosit CD4+ berperan sebagai pengatur utama respon imun, terutama melalui sekresi limfokin. Sebagian zat kimia yang dihasilkan T-helper berfungsi sebagai kemotaksin dan peningkatan kerja makrofag, monosit, dan sel Natular Killer. Kerusakan sel T-helper oleh HIV menyebabkan penurunan sekresi antibodi dan gangguan pada sel imun lainnya. ${ }^{20}$

Seseorang dengan imunokompeten terinfeksi kuman TB, makrofag akan memfagosit kuman yang masuk dan sel CD4+ berperan dalam meningkatkan kapasitas fagosit makrofag, sehingga kuman TB tidak berkembang dan tidak akan timbul sakit TB. ${ }^{21}$ Pada orang yang terinfeksi HIV, secara perlahan kadar CD4+ turun menjauhi kadar normal ${ }^{1}$. Pasien dengan kadar CD4+ kurang dari 200/ $\mu$ l darah akan mengalami imunosupresi yang berat dan keadaan ini merupakan risiko tinggi untuk terjangkit infeksi oportunistik. ${ }^{22}$ 
Penurunan kadar dan disfungsi sel CD4 yang progresif, ditambah dengan adanya kerusakan fungsi makrofag dan monosit pada penderita HIV menjadi predisposisi untuk terjadinya sakit TB. ${ }^{21}$ Diperkirakan pasien HIV yang terinfeksi TB lebih berisiko untuk mengalami perkembangan menjadi sakit TB sebanyak 21 - 34 kali, $^{23}$ dan sekitar $60 \%$ pasien HIV yang terinfeksi TB akan menjadi sakit TB. ${ }^{24}$

Peningkatan ini dibandingkan dengan estimasi nasional mungkin dikarenakan meningkatnya angka kasus HIV di Sumatera Barat (Sumbar) terutama di kota Padang, sesuai dengan laporan Badan Perencanaan Pembangunan Daerah (BAPPEDA) yang menyatakan bahwa jumlah kasus HIVIAIDS di provinsi Sumatera Barat mengalami peningkatan sejak tahun 2007 sebanyak lebih 100 kasus baru per tahunnya, dan pada tahun 2013 ditemukan 348 kasus HIVIAIDS di kota Padang. ${ }^{25}$

Tabel 3. Distribusi frekuensi responden berdasarkan riwayat $\mathrm{DM}$

\begin{tabular}{ccc}
\hline Riwayat DM & $\mathbf{f}$ & $\%$ \\
\hline Ada & 8 & 12,3 \\
Tidak ada & 57 & 87,7 \\
\hline Jumlah & 65 & 100 \\
\hline
\end{tabular}

Berdasarkan Tabel 3, tampak bahwa sebagian besar penderita TB paru tidak memiliki riwayat DM yaitu sebesar $87,7 \%$.

Data sekunder yang didapatkan dari rekam medis pasien, frekuensi pasien TB paru dengan riwayat DM didapatkan lebih banyak pada laki laki dibandingkan perempuan (5:3) dengan persentase 62,5\%:37,5\%, sebagaimana temuan Zhao et al yang dikutip oleh Widjayanto et al mengatakan bahwa lakilaki penderita DM umumnya dianggap lebih berisiko TB dibandingkan perempuan, tetapi belum ditemukan alasan yang jelas. ${ }^{26}$

WHO memperkirakan $10 \%$ dari kasus TB berhubungan dengan $\mathrm{DM},{ }^{27}$ dan juga pada penelitian sebelumnya dilaporkan frekuensi DM pada pasien TB sekitar $10-15 \%{ }^{28}$

Diabetes merupakan salah satu faktor yang meningkatkan risiko timbulnya sakit TB, diperkirakan sepertiga kasus DM akan terinfeksi TB. Pasien diabetes $2-3$ kali berisiko menderita TB dibandingkan non diabetes. ${ }^{27}$ Penyebab meningkatnya insiden tuberkulosis paru pada pasien diabetes mungkin karena adanya gangguan respon selular pada pasien DM yang mengakibatkan melemahnya sistem imun tubuh, sehingga meningkatkan risiko aktivasi TB laten. $^{29}$

Pada orang sehat, kuman TB yang masuk dan menginfeksi tubuh akan dihadang oleh sel PMN (Poli Morfo Nuklear) dan difagosit oleh makrofag. Namun pada penederita DM, kemampuan mobilisasi, kemotaksis dan fagositosis dari sel PMN menurun akibat kondisi hiperglikemia, sehingga aktivitas bakterisid dari PMN pada penderita DM menurun. Selain sel PMN, sel mononuklear juga mengalami penurunan secara kuantitatif, demikian juga kemampuan deteksinya terhadap mikroorganisme juga menurun, diduga akibat penurunan sensitivitas reseptor atau penurunan jumlah reseptor yang ada pada monosit tersebut.

Penurunan sistem imun dan rentannya jaringan terhadap kerusakan terjadi akibat glucotoxicity pada DM. Glucotoxicity diartikan sebagai proses kerusakan yang timbul akibat adverse effect hiperglikemi kronis. ${ }^{30}$ Gangguan aktivitas dan lemahnya daya imun seluler menyebabkan sel-sel imun tidak mampu menghadang dan memfagosit kuman TB yang menginfeksi tubuh, akibatnya kuman TB terus berkembang dan menimbulkan sakit TB pada orang tersebut.

Tabel 4. Distribusi frekuensi responden berdasarkan riwayat alkohol

\begin{tabular}{ccc}
\hline $\begin{array}{c}\text { Riwayat konsumsi } \\
\text { alkohol }\end{array}$ & $\mathbf{f}$ & $\%$ \\
\hline Berisiko & 1 & 1,5 \\
Tidak berisiko & 64 & 98,5 \\
\hline Jumlah & 65 & 100 \\
\hline
\end{tabular}

Berdasarkan Tabel 4, terlihat bahwa sebesar 98,5\% penderita TB paru bukan kelompok berisiko. Hasil wawancara yang didapatkan dari 65 responden hanya $1,5 \%$ yang tergolong berisiko diantara 17 orang $(26,2 \%)$ yang pernah mengonsumsi minuman beralkohol. Menurut Lonnorth et al prevalensi kelompok berisiko (konsumsi alkohol berat atau alkoholism) pada pasien TB mencapai 10\% - 50\%. ${ }^{31}$ Penelitian yang dilakukan di RS Cipto Mangunkusomo 
pada tahun 2010 didapatkan 14,4\% pasien TB paru memiliki riwayat konsumsi alkohol, namun pada penelitian ini tidak memperhitungkan banyaknya yang diminum. $^{9}$ Dinilai berdasarkan frekuensi minum didapatkan sebagian kecil minum setiap hari (3 orang), satu kali seminggu (3 orang), dan tidak rutin (conditional) sebanyak 11 orang dengan banyaknya minum 1 sloki hingga 3 botol per kali minum.

Hasil ini memperlihatkan bahwa mengonsumsi minuman beralkohol bukan merupakan kebiasaan masyarakat Sumatera Barat terutama masyarakat kota Padang, tidak seperti di negara maju yang kebanyakan masyarakatnya memiliki kebiasaan sering atau bahkan setiap hari mengonsumsi alkohol. Hal ini sesuai dengan data WHO yang mengatakan bahwa tingkat konsumsi alkohol di Indonesia tidak terlalu tinggi jika dibandingkan dengan negara negara di Eropa seperti Jerman, Rusia dan negara lain seperti Argentina, New Zealand dan Australia. ${ }^{9}$

Alkohol menimbulkan efek toksik baik langsung ataupun tidak langsung melalui defisiensi makronutrien dan mikronutrien akibat konsumsi alkohol yang menyebabkan melemahnya sistem imun. Pengonsumsian alkohol secara kronik menyebabkan penurunan fungsi limfosit $T$ dan $\mathrm{B}^{32}$ Pada pengonsumsian alkohol baik akut maupun kronik terjadi gangguan fungsi makrofag dan sistem imun yang diperantarai sel, selain itu juga terjadi inhibisi dari TNF, NO, IL-2, IFN gamma, proliferasi CD4+, sehingga proses destruksi dari Mycobacterium tuberculosis menjadi terhambat. ${ }^{31}$

Pada suatu studi in vitro ditemukan bahwa pertumbuhan dan kemampuan hidup kuman TB pada makrofag meningkat dengan pajanan alkohol. Gangguan lain pada sistem imun juga ditemukan akibat pajanan kronik alkohol, diantaranya adalah gangguan aktivasi makrofag, berkurangnya kemampuan makrofag untuk mempresentasikan antigen ke sel $\mathrm{T}$, berkurangnya respon makrofag terhadap sitokin, terjadi pergeseran ke arah pembentukan Th2, sehingga jumlah Th1 yang berperan pada proses destruksi Mycobacterium tuberculosis terhambat, kondisi ini menyebabkan aktivasi kuman TB meningkat. ${ }^{33}$ Belum ada penelitian yang menyatakan adanya hubungan kebiasaan meminum alkohol ringan sampai sedang dengan risiko timbulnya TB, namun konsumsi alkohol berat lebih dari 40 gram per hari atau alkoholism meningkatkan risiko hingga 3,5 kali untuk mengidap sakit TB. ${ }^{31}$

Tabel 5. Distribusi frekuensi responden berdasarkan status gizi

\begin{tabular}{ccc}
\hline IMT & f & $\%$ \\
\hline Gizi Kurang & 43 & 66,1 \\
Gizi Cukup & 20 & 30,8 \\
Gizi Lebih & 2 & 3,1 \\
\hline Jumlah & 65 & 100 \\
\hline
\end{tabular}

Berdasarkan Tabel 5, terlihat bahwa lebih dari separuh pasien TB paru memiliki status gizi kurang sebesar $66,1 \%$.

Hasil penelitian ini memperlihatkan jumlah pasien dengan status gizi kurang lebih banyak dibandingkan dengan gizi cukup dan gizi lebih, dengan perbandingan $66,1 \%: 30,8 \%: 3,1 \%$. Angka ini sejalan dengan penelitian Supriyo et al di Pekalongan tentang TB yang mendapatkan hasil status gizi kurang dengan IMT <18,5 pada kelompok kasus sebanyak $58,6,{ }^{34}$ dan juga sesuai dengan penelitian yang dilakukan oleh Arsin, et al., di Makasar pada tahun 2012 dengan hasil persentase responden yang memiliki status gizi kurang lebih besar (51,3\%) dibandingkan responden yang memiliki status gizi normal $(40,7 \%)$ dan gemuk $(8,0 \%){ }^{35}$

Pada infeksi TB dengan malnutrisi terjadi gangguan sistem imun akibat penurunan produksi limfosit dan kemampuan proliferasi sel imun. Hal ini disebabkan oleh penurunan kadar IFN-gamma, IL-2 dan peningkatan kadar TGF- $\beta$ yang berfungsi untuk menghambat aktivasi makrofag. ${ }^{36}$ Pada kondisi kekurangan gizi, ditemukan adanya gangguan berbagai aspek imunitas, termasuk fagositosis, respon proliferasi sel, serta produksi limfosit T dan sitokin. ${ }^{37}$

Jumlah pasien TB paru dengan status gizi kurang melebihi $50 \%$ dibandingkan dengan pasien TB paru yang memiliki status gizi cukup dan gizi lebih. Perbedaan yang besar ini mungkin bisa mendukung penelitian sebelumnya yang menyatakan bahwa kondisi malnutrisi (terutama status gizi kurang) meningkatkan risiko terjadinya sakit TB. Dalam ilmu 
epidemiologi, untuk menilai suatu kausalitas itu nyata atau tidak, harus memenuhi beberapa kriteria. Hill (1965) dalam Mahmudiono (2012) merumuskan sembilan kriteria kausalitas, salah satunya temporality yang mengacu pada perlunya suatu kausa mendahului suatu outcome yang diasumsikan sebagai efek dari kausa tersebut. ${ }^{38}$ Pada penelitian ini sulit dinilai apakah gizi kurang pada pasien terjadi sebelum atau setelah sakit TB.

Tabel 6. Distribusi frekuensi responden berdasarkan riwayat merokok

\begin{tabular}{ccc}
\hline Klasifikasi & $\mathbf{f}$ & $\%$ \\
\hline Current smoker & 1 & 1,5 \\
Former smoker & 39 & 60 \\
Never smoker & 25 & 38,5 \\
\hline Jumlah & 65 & 100 \\
\hline
\end{tabular}

Berdasarkan Tabel 6, tampak bahwa lebih dari separuh pasien TB paru merupakan mantan perokok (former smoker) yaitu sebesar $60 \%$.

Hasil penelitian ini menunjukkan 40 responden $(61,5 \%)$ memiliki riwayat merokok dimana sebagian besar merupakan merupakan former smoker (mantan perokok) dengan persentase $60 \%$. Angka ini sejalan dengan angka kejadian merokok pada pasien TB paru yang diteliti oleh Widyanita et al di Manado yaitu $57,9 \%{ }^{39}$ Berdasarkan penelitian yang dilakukan di Makasar pada pasien yang berkunjung ke Poli Paru RSUP Denpasar didapatkan angka $76,1 \%$ pasien yang sebelumnya pernah merokok dari 46 orang sampel yang didiagnosis TB Paru. ${ }^{40}$

Hasil wawancara yang dilakukan pada responden yang tergolong former smoker dan current smoker 15 orang telah merokok selama lebih dari 20 tahun dan yang memiliki Indeks Brinkman (IB) berat sebanyak 12 orang selebihnya IB sedang (12 orang) dan IB ringan (16 orang). Pasien former smoker merupakan pasien TB Paru yang memiliki riwayat merokok dan pada saat dilakukan penelitian sudah berhenti merokok, umumnya pasien berhenti merokok setelah didiagnosis oleh dokter menderita penyakit TB Paru $(30,7 \%)$ dan yang lainnya mengaku sudah berhenti merokok beberapa tahun sebelum sakit TB.
Merokok menjadi salah satu faktor risiko yang meningkatkan kejadian TB akibat penurunan daya tahan tubuh dan kerusakan saluran pernafasan pada orang yang sering merokok.

\section{SIMPULAN}

Hampir semua penderita TB paru bukan kelompok berisiko berdasarkan riwayat konsumsi alkohol.

Lebih dari separuh penderita TB paru memiliki status gizi kurang.

Sebagian besar penderita TB paru merupakan former smoker (mantan perokok).

\section{UCAPAN TERIMA KASIH}

Terimakasih kepada semua pihak yang telah bersedia memberikan saran yang membangun dalam penelitian ini dan kepada Direktur RSUP Dr. M Djamil Padang, Kepala bagian beserta staf Poli Paru RSUP Dr. M Djamil Padang yang sudah membantu sehingga penelitian ini bisa penulis selesaikan dengan baik dan tepat waktu, serta kepada responden yang telah ikut membantu penulis selama penelitian.

\section{DAFTAR PUSTAKA}

1. Perhimpunan Dokter Paru Indonesia (PDPI). Tuberkulosis: pedoman diagnosis dan penatalaksanaan di Indonesia. Jakarta: PDPI; 2011.

2. World Health Organization (WHO). Fact Sheet No 104. WHO; 2011.

3. PDPI. Tuberkulosis: pedoman diagnosis dan penatalaksanaan di Indonesia. Jakarta: Perhimpunan Dokter Paru Indonesia. 2006.

4. Dinas Kesehatan Kota Padang. Profil kesehatan tahun 2013. Dinas Kesehatan Kota Padang; 2014.

5. Kementrian Kesehatan RI. Riset kesehatan dasar. Kementrian Kesehatan RI; 2013

6. Narasimhan P, Wood J, Maclntyree CR, Mathai D. Review article: risk factors for tuberculosis. Hindawi Publishing Corporation. Pulmonary Medicine; 2013.

7. Kementrian Kesehatan RI. Penanggulangan tuberkulosis terpadu- TB Indonesia. Kementrian Kesehatan RI; 2015. 
8. Nazulis RA. Drug related problem pada pasien diabetes melitus tipe 2 dengan tuberkulosis paru di bangsal penyakit dalam dan poliklinik RSUP.Dr.M.Djamil Padang (artikel penelitian). Padang: Fakultas Kedokteran Universitas Andalas; 2011.

9. Erick. Hubungan antara konsumsi alkohol dengan prevalensi tuberkulosis paru pada pasien diabetes mellitus tipe 2 di rumah sakit Cipto Mangunkusumo tahun 2010. Jakarta: Fakultas Kedokteran Universitas Indonesia (FKUI); 2012.

10. Panjaitan F. Karakteristik penderita tuberkulosis paru dewasa rawat inap di rumah sakit umum DR. Soedarso Pontianak periode September November 2010. Pontianak: Fakultas Kedokteran dan IImu Kesehatan Universitas Tanjungpura; 2012.

11. Sarwani D, Nurlela S, Zahrotul I. Faktor risiko multidrug resistant tuberculosis (MDR-TB). Jurnal Kesehatan Masyarakat. 2012;8:60-6.

12. Masniari L. Penilaian hasil pengobatan TB paru dan faktor- faktor yang mempengaruhinya serta alasan putus berobat di RS Persahabatan Jakarta. Jakarta: Bagian Pulmonologi dan IImu Kedokteran Respirasi FKUI; 2004

13. Zaman K. Tuberculosis: a global health problem. J Health Popul Nutr. 2010;28:111-3.

14. Watkins RE, Plant AJ. Does smoking explain sex differences in the global tuberculosis epidemic infect. Cambridge University Press. Epidemiol Infect. 2006;134:333-9.

15. Departemen Kesehatan RI. Survei prevalensi tuberkulosis di Indonesia tahun 2004. Jakarta: Badan Litbang DepKes; 2005.

16. Gooze L, Daley CL. Tuberculosis and HIV. San Fransisco: University of California; 2013.

17. Kementrian Kesehatan RI. Strategi nasional pengendalian TB di Indonesia 2010-2014. Kementrian Kesehatan RI; 2011.

18. Kementrian Kesehatan RI. Keputusan menteri kesehatan (KEPMENKES) RI nomor 1278/ MENKES/SK/XII/2009. Jakarta: Kementrian Kesehatan RI; 2009.

19. Simbolon E. Pola kelainan kulit pada pasien HIV/ AIDS di RSUP Haji Adam Malik (artikel penelitian). Medan: Universitas Sumatera Utara; 2011.
20. Murtiastutik D. AIDS. Dalam: Barakhbah J, editor (penyunting). Buku Ajar infeksi menular seksual. Surabaya: Airlangga University Press; 2008.

21. Bhatia RS. HIV and tuberculosis: the ominous connection. IJCP. 2001.

22. Lan VM. Virus Imunodefisiensi Manusia (Hiv) dan Sindrom Imunodefisiensi Didapat (AIDS). Dalam: Hartanto $\mathrm{H}$, (penterjemah). Patofisiologi: konsep klinis proses- proses penyakit. Jakarta: EGC; 2006.

23. World Health Organization (WHO). TB/HIV facts 2012-2013. WHO; 2013.

24. Wijaya IMK. Infeksi HIV (human immunodeficiency virus) pada penderita tuberkulosis. Procc MIPA 3. 2013: 295-303.

25. BAPPEDA SUMBAR. Kajian pengembangan strategi penanggulangan HIVIAIDS melalui pendekatan sosial budaya. BAPPEDA SUMBAR; 2015.

26. Widjayanto A, Burhan E, Nawas A, Rochsis mandoko. Faktor terjadinya tuberkulosis paru pada pasien diabetes mellitus tipe 2. J Respir Indo. 2015;35:1-11.

27. World Health Organization (WHO). Tuberculosis \& diabetes. WHO; 2011.

28. Cahyadi A, Venty. Tuberkulosis paru pada pasien diabetes mellitus. Departemen IImu Penyakit Dalam Fakultas Kedokteran Universitas Kristen Atma Jaya. RS Atma Jaya. Jakarta: J Indon Med Assoc. 2011.

29. Restrepo $\mathrm{BI}$, et al.Tuberculosis in poorly controlled type 2 diabetes: altered cytokine expression in peripheral white blood cells. Clin Infect Dis. 2008; 47:634-41.

30. Manaf A. Genetical Abnormality and glucotoxicity in DM. Sub Bagian Metabolik Endokrin. Padang: Bagian IImu Penyakit Dalam Fakultas Kedokteran Universitas Andalas; 2008.

31. Lonnorth K, Williams BG, Stadlin S, Jaramillo E, Dye C. Alcohol use as a risk factor for tuberculosisa systematic review. BMC Public Health. 2008;8:289.

32. Diandini R, Roestam AW, Yunus F. Pengaruh pekerjaan dengan pajanan debu silika terhadap risiko tuberkulosis. Maj Kedokt Indon. 2009;59: 412-7. 
33. Rehm J, Samokhvalov AV, Neuman MG, Room R, Parry C, Lonnorth $\mathrm{K}$, et al. The Association between alcohol use, alcohol use disorders and tuberculosis (TB). BMC Public Health. 2009;9:450.

34. Supriyo, Baequny A, Hidayati $S$, Hartono $M$, Harnany AS. Pengaruh perilaku dan status gizi terhadap kejadian TB paru di kota Pekalongan. Pena Medika Jurnal Kesehatan. 2013;4:1-8.

35. Arsin AA, Wahiduddin, Anshar J. Gambaran asupan zat gizi dan status gizi penderita TB paru di kota Makassar. Makassar:Universitas Hasanuddin; 2012.

36. Pratomo IP, Burhan E, Tambunan V. Malnutrisi dan tuberkulosis. J Indon Med Assoc. 2012.
37. Siagan A. Gizi, imunitas, dan penyakit infeksi. Medan: Departemen Gizi dan Kesehatan Masyarakat Fakultas Kesehatan Masyarakat Universitas Sumatera Utara; 2010.

38. Mahmudiono T. Kriteria kausalitas Hill. web mahasiswa Universitas Airlangga. 2012.

39. Widyanita KS, Wongkar MCP, Langi Y A. Angka kejadian merokok pada pasien TB paru yang berobat di poliklinik Dots pada bulan November 2014. Jurnal e-Clinic. 2015;3:408 - 11.

40. Sajinadiyasa IGK, Bagiada IM, Ngurah Rai IB. Prevalensi dan risiko merokok terhadap penyakit paru di poliklinik paru rumah sakit umum pusat Sanglah, Denpasar. Journal of Internal Medicine. 2010;11:91 - 5 . 